\title{
PENINGKATAN PROSES PEMBELAJARAN TEMATIK TERPADU MENGGUNAKAN MODEL COOPERATIVE INTEGRATED READING AND COMPOSITION ( CIRC) DI KELAS IV SD NEGERI 06 PIAI TANGAH KOTA PADANG
}

\author{
Ririn Desma Rosha ${ }^{1}$, Reinita ${ }^{2}$ \\ ${ }^{12}$ PGSD FIP Universitas Negeri Padang \\ 1ririndesmarsh17@.gmail.com, ${ }^{2}$ reinita1652@fip.unp.ac.id \\ Nomor HP : ${ }^{1} 085268228870$
}

\begin{abstract}
This research was conducted to describe the improvement of the integrated thematic learning process using the Cooperative Integrated Reading and Composition (CIRC) model in class IV elementary school 06 Piai Tangah, Padang City. This research includes classroom action research using qualitative and quantitative approaches with the research subjects of grade IV students totaling 28 people. The results showed an increase in the integrated thematic learning process using the CIRC model. This is evidenced by the percentage of the RPP assessment in the first cycle obtained an average of $79.16 \%$ with good criteria (B) and an increase of $97.22 \%$ with very good criteria (SB) in the second cycle. In the teacher aspect of cycle I with an average of $83.92 \%$ with good criteria (B) and an increase of $92.85 \%$ with very good criteria (SB) in cycle II. Then in the aspect of cycle I students obtained an average value of $83.92 \%$ with good criteria (B) and increased $92.85 \%$ with very good criteria (SB) in cycle II. Thus, it can be concluded that the CIRC model can improve the integrated thematic learning process in class IV elementary school 06 Piai Tangah Kota Padang.
\end{abstract}

Keywords: CIRC, learning process, integrated thematic

\section{ABSTRAK}

Penelitian inidilakukan untuk mendeskripsikan peningkatan proses pembelajaran tematik terpadu menggunakan model Cooperative Integrated Reading and Composition (CIRC) di kelas IV SD Negeri 06 Piai Tangah Kota Padang. Penelitian yang dilakukan ini termasuk penelitian tindakan kelas menggunakan pendekatan kualitatif dan kuantitatif dengan subyek penelitian peserta didik kelas IV yang berjumlah 28 orang. Hasil penelitian menunjukan peningkatan proses pembelajaran tematik terpadu mengunakan model CIRC. Hal ini dibuktikan dengan persentase penilaian RPP pada siklus I memperoleh ratarata $79,16, \%$ dengan kriteria baik (B) dan meningkat $97,22 \%$ dengan kriteria sangat baik (SB) pada siklus II. Pada aspek guru siklus I dengan rata-rata 83,92\% dengan kriterian baik (B) dan meningkat 92,85\% dengan kriterian sangat baik (SB) 
pada siklus II. Kemudian pada aspek siswa siklus I memperoleh nilai rata-rata $83,92 \%$ dengan kriterian baik (B) dan meningkat 92,85\% dengan kriterian sangat baik (SB) pada siklus II. Dengan demikian, dapat disimpulkan bahwa model CIRC dapat meningkatkan proses pembelajaran tematik terpadu di kelas IV SD Negeri 06 Piai Tangah Kota Padang.

Kata Kunci: CIRC, proses pembelajaran , tematik terpadu

\section{A. Pendahuluan}

Pembelajaran yang diterapkan dalam kurikulum 2013 adalah pembelajaran tematik yaitu memadukan beberapa muatan pelajaran menjadi satu tema dengan tujuan memberikan kontribusi dalam peningkatan kualitas pembelajaran. Tujuan pendidikan nasional diwujudkan melalui tercapainya tujuan setiap pembelajaran yang dituangkan secara menyeluruh dalam kurikulum setiap pembelajaran (Reinita, 2019). Pada jenjang pendidikan dasar, penerapan pembelajaran kurikulum 2013 dilaksanakan melalui pendekatan pembelajaran tematik, yaitu pembelajaran yang berorientasi pada pemetaan tema pembelajaran. Karena pembelajaran tematik pada hakikatnya tidak hanya sebatas integrasi mata pelajaran, namun merupakan pembelajaran bermakna yang mana konsepkonsep materi dan aspek-aspek kompetensi juga harus terintegrasi dalam proses pembelajaran.

Proses

pembelajaran

merupakan bagian

yang berpengaruh terhadap tercapai tidaknya tujuan embelajaran, tergantung proses pembelajaran yang dilaksanakan guru. Menurut Windhasari, (2015) Melalui interaksi pembelajaran antara peserta didik dengan guru dan sumber belajar untuk dapat mencapai tujuan dan hasil pengajaran yang diinginkan. Proses pembelajaran seperti ini akan berjalan maksimal apabila dalam proses pembelajaran tematik terpadu diterapkan salah satu model yang bisa membuat peserta didik aktif dan mampu mengembangkan nilai dan karaktek terhadap diri peserta didik sendiri dalam kehidupan nyata. Selain menyesuaikan model dengan kondisi peserta didik seorang guru perlu merancang Rencana Pelaksanaan Pembelajaran (RPP) yang berisi kegiatan pembelajaran sebelum memulai pembelajaran. Rencana Pelaksanaan Pembelajaran (RPP) dikembangkan dari silabus untuk mengarahkan kegiatan pembelajaran peserta didik dalam upaya mencapai Kompetensi Dasar (KD). Menurut Permendikbud No. 22 Tahun 2016 komponen-komponen dari RPP meliputi; Identitas sekolah, identitas tema/subtema, kelas/semester, materi pokok alokasi waktu, kompetensi inti, kompetensi dasar dan indikator, tujuan pembelajaran, materi pembelajaran, metode pembelajaran, media, alat dan sumber pembelajaran, langkahlangkah kegiatan pembelajaran, dan penilaian. Keterbatasan sumber bacaan, buku referensi, dan kondisi 
lingkungan baik sekolah maupun masyarakat menjadi kendala bagi guru untuk menerapkan pembelajaran seutuhnya.

Berdasarkan hasil observasi yang peneliti lakukan pada hari Rabu, 25 November 2020, hari kamis 26 November 2020, hari juma'at 27 November 2020 di kelas IV SD Negeri 06 Piai Tangah Kota Padang peneliti menemukan beberapa permasalahan pada Rencana Pelaksanaan Pembelajaran (RPP), yaitu 1) Indikator yang diturunkan belum menggunakan KKO (kata kerja operasional), 2) Tujuan pembelajaran belum menggunakan unsur audience (A), behavior (B), condition (C) degree (D), 3) RPP yang digunakan belum dilampirkan instrumen penilaian 4) RPP belum dimodifikasi dengan menggunakan model pembelajaran yang sesuai dengan situasi, kondisi, dan karakteristik peserta didik. Masalah yang peneliti lihat dari rangkaian proses pembelajaran diantaranya: 1) Guru belum menggunakan model pembelajaran yang tepat sesuai dengan situasi, kondisi, dan karakteristik peserta didik 2) guru kurang memberi kesempatan kepada peserta didik untuk berpendapat 3) guru lebih sering memberikan tugas secara individu 4).

Hal tersebut akan berdampak pada peserta didik, diantaranya adalah: 1) peserta didik kurang memahami materi pembelajaran 2) peserta didik kurang percaya diri saat proses pembelajaran 3) aktifitas peserta didik kurang terlaksana karena mulai bosan terhadap pembelajarannya, 4) peserta didik belum sepenuhnya berpartisipasi aktif 5) peserta didik kurang termotivasi untuk belajar karena sering belajar secara indivivu 6) peserta didik kurang terlatih mengembangkan keterampilan berpikir dalam memecahkan masalah dalam pembelajaran.

Untuk mengatasi permasalahan tersebut perlu adanya perbaikan proses pembalajaran dalam pembelajaran tematik terpadu salah satunya dengan menggunakan model pembelajaran yang inofatif. Model cooperative yaitu model yang mengajak peserta didik bekerja secara kelompok kecil dan memiliki tanggung jawab terhadap tugas dalam kelompok. hal tersebut sesuai dengan pendapat yang menyebutkan bahwa model cooperative learning menitikberatkan siswa untuk saling membantu mengerjakan penugasan antar anggota kelompok sebagai satu tim (siddiq \& Reinita, 2019). Model cooperative ini sendiri memiliki beberapa tipe salah satunya yaitu Cooperative Integrated Reading and Composition (CIRC) merupakan suatu model pembelajaran kooperatif yang mengintegrasikan bacaan secara menyeluruh kemudian mengomposisikannya menjadi bagian-bagian yang penting. Menurut Faturrhoman (2015) CIRC (cooperative integrated reading and composition) adalah sebuah model pembelajaran yang sengaja dirancang untuk mengembangkan kemampuan membaca menulis dan keterampilan lainnya. CIRC dari 
segi bahasa dapat
diartikan sebagai suatu model

pembelajaran kooperatif yang mengintegrasikan bacaan secara menyeluruh kemudian mengomposisikannya menjadi bagian-bagian yang penting, tujuan utama dari model CIRC ini adalah menggunakan tim-tim kooperatif untuk membantu para peserta didik mempelajari kemampuan memahami bacaan yang dapat diaplikasikan secara luas.

Adapun kelebihan dari model CIRC yaitu menigkatkan semngat belajar peserta didik karena belajar dalam kelompok, dan juga peserta didik lebih aktif sehingga guru tidak dominan saat proses pembelajaran. Sesuai dengan salah satu pendapat yang menyatakan kelebihan model CIRC sangat tepat untuk 1) meningkatkan keterampilan peserta didik dalam menyelesaikan soal pemecahan masalah 2) Dominasi guru dalam pembelajaran berkurang 3) Peserta didik termotivasi pada hasil secara teliti karena bekerja dalam kelompok 4) para peserta didik dapat memahami makna soal dan saling mengecek pekerjaannya 5) membantu peserta didik yang lemah

6) meningkatkan hasil belajar khususnya dalam menyelesaikan soal yang berbentuk pemecahan masalah (Shoimin, 2014). Sehingga dengan penerapan model ini dapat meningkatkan proses pembelajaran tematik terpadu karena bekerja secara kelompok kemudian peserta didik dapat lebih memahami makna pembelajaran dan saling mengecek pekerjaan.
Berdasarkan uraian di atas peneliti melakukan penelitian dengan rumusan masalah Bagaimanakah rencana pelaksanaan pembelajaran untuk Peningkatan Proses Pembelajaran Tematik Terpadu Menggunakan Model Cooperative Integrated Reading and Composition (CIRC) Di Kelas IV SDN 06 Piai Tangah Kota Padang, dan Bagaimanakah pelaksanaan pembelajaran untuk Peningkatan Proses Pembelajaran Tematik Terpadu Menggunakan Model Cooperative Integrated Reading and Composition (CIRC) Di Kelas IV SDN 06 Piai Tangah Kota Padang. Penelitian ini bertujuan untuk mendeskripsikan

Rencana pelaksanaan pembelajaran untuk peningkatan proses pembelajaran tematik terpadu menggunakan model Model Cooperative Integrated Reading and Composition (CIRC) Di Kelas IV SDN 06 Piai Tangah Kota Padang, dan Pelaksanaan pembelajaran untuk peningkatan proses pembelajaran tematik terpadu menggunakan Model Cooperative Integrated Reading and Composition (CIRC) Di Kelas IV SDN 06 Piai Tangah Kota Padang.

\section{B. Metode Penelitian}

Penelitian ini dilaksanakan di SD Negeri 06 Piai tangah Kota Padang dengan subyek penelitian peserta didik kelas IV berjumlah 28 orang. Penelitiian ini dilaksanakan pada semester genap pertemuan I siklus I pada hari Senin 8 Maret 2021, pertemuan II siklus I pada hari Selasa 9 Maret 2021, dan siklus II pertemuan 1 hari Selasa 16 Maret 2021 tahun 
ajaran 2020/2021 di kelas IV SD Negeri 06 Piai tangah Kota Padang. Penelitian ini dilakukan selama dua siklus, setiap siklusnya terdiri dari empat tahapan yaitu perencanaan, tindakan, pengamatan dan refleksi. penelitian ini menggunakan analisis data kualitatif dan kuantitatif, pendekatan ini digunakan untuk melihat kondisi sebenarnya dan digunakan analisi data yang diperlukan. Senada dengan pendapat Audina \& Reinita (2019) pendekatan kualitatif digunakan untuk meneliti kondisi kondisi alamiah yang sebenarnya terjadi di lapangan saat penelitian, sedangkan memantau keberhasilan proses pembelajaran dengan pendekatan kualitatif ini didukung oleh pendekatan kuantitatif.

Data kuantitatif menggunakan persentase yang dikemukakan dalam Kemendikbud (2014), untuk menghitung hasil ranah afektif, kognitif dan psikomotor digunakan rumus:

Nilai akhir $=$ Rata-rata dari semua nilai

Tabel 3.1 Indeks nilai kuantitatif dengan skala, sebagai berikut:

\begin{tabular}{|c|c|c|c|}
\hline \multicolumn{2}{|c|}{$\begin{array}{l}\text { Konversi } \\
\text { nilai akhir }\end{array}$} & \multirow{2}{*}{$\begin{array}{c}\text { Preidkat } \\
\text { pengeta } \\
\text { huan } \\
\text { dan } \\
\text { keteram } \\
\text { pulan }\end{array}$} & \multirow{2}{*}{$\begin{array}{l}\text { Klasifikasi } \\
\text { sikap dan } \\
\text { ekstrakulik } \\
\text { uler }\end{array}$} \\
\hline $\begin{array}{l}\text { Ska } \\
\text { a } 0- \\
100\end{array}$ & $\begin{array}{c}\text { Skal } \\
\text { a } 0- \\
4\end{array}$ & & \\
\hline $\begin{array}{l}86- \\
100 \\
\end{array}$ & 4 & A & \multirow[t]{2}{*}{$\begin{array}{c}\text { SB (Sanga } \\
\text { Baik) }\end{array}$} \\
\hline $\begin{array}{l}81- \\
85\end{array}$ & 3,66 & $\mathbf{A}^{-}$ & \\
\hline $\begin{array}{l}76- \\
80 \\
\end{array}$ & 3,33 & $\mathbf{B}^{+}$ & \multirow[t]{2}{*}{ B (Baik) } \\
\hline $\begin{array}{l}71- \\
75 \\
\end{array}$ & 3,00 & B & \\
\hline
\end{tabular}

\begin{tabular}{|c|c|c|c|}
\hline $\begin{array}{l}\text { 66- } \\
70\end{array}$ & 2,66 & $\mathbf{B}^{-}$ & \\
\hline $\begin{array}{l}61- \\
65\end{array}$ & 3,33 & $\mathrm{C}^{+}$ & \multirow[t]{3}{*}{ C (Cukup) } \\
\hline $\begin{array}{c}56- \\
60\end{array}$ & 2 & C & \\
\hline $\begin{array}{c}51- \\
55\end{array}$ & 1,66 & $\mathrm{C}^{-}$ & \\
\hline $\begin{array}{c}46- \\
50\end{array}$ & 1,33 & $\mathbf{D}^{+}$ & \multirow[t]{2}{*}{ K (Kurang) } \\
\hline $0-45$ & 1 & D & \\
\hline
\end{tabular}

Untuk menghitung persentase hasil pengamatan praktik pembelajaran menurut Kemendikbud (2014) dengan rumus sebagai berikut:

nilai

$=\frac{\text { jumlah skor yang diperoleh }}{\text { jumlah skor maksimal }} \times 100 \%$

Tabel

3.2 Kriteria taraf

keberhasilan, dapat ditentukan sebagai berikut:

\begin{tabular}{|c|c|}
\hline Peringkat & Nilai \\
\hline $\begin{array}{c}\text { Sangat Baik } \\
\text { (SB) }\end{array}$ & $\mathbf{9 0}<\mathbf{S B} \leq \mathbf{1 0 0}$ \\
\hline Baik (B) & $\mathbf{8 0}<$ B $\leq \mathbf{9 0}$ \\
\hline Cukup (C) & $\mathbf{7 0}<\mathbf{C} \leq \mathbf{8 0}$ \\
\hline Kurang (K) & $\leq 70$ \\
\hline
\end{tabular}

\section{C.Hasil Penelitian dan Pembahasan}

Pelaksanaan tindakan dibagi atas 2 siklus. Setiap siklus dimulai dengan kegiatan perencanaan pembelajaran, pelaksanaan pembelajaran, pengamatan dan refleksi. Selama melaksanakan penelitian, peneliti berkolaborasi dengan guru kelas IV di SDN 06 Piai Tangah Kota Padang. Dalam pelaksanaan tindakan pembelajaran peneliti bertindak sebagai praktisi (guru) dan guru kelas sebagai 
pengamat (observer). Pembelajaran tematik terpadu dilaksanakan sesuai dengan model CIRC menurut Shoimin (2014) : 1) Membentuk kelompok yang anggotanya 4 orang yang secara heterogen 2) Guru memberikan wacana/kliping sesuai dengan topik pembelajaran 3) Peserta didik bekerjasama saling membacakan dan menemukan ide pokok dan memberi tanggapan terhadap wacana/kliping dan ditulis pada lembar kertas 4) mempresentasikan/membacakan hasil kelompok 5) guru membuat kesimpulan bersama 6) penutup.

\section{Siklus I}

Dalam peningkatan proses pembelajaran tematik terpadu menggunakan model CIRC ini, perencanaan pembelajaran (RPP) tematik terpadu disusun menggunakan model CIRC. Siklus I pertemuan I dilaksanakan pada hari

Senin 8 maret 2021 pada tema 8 "Daerah tempat tinggalku", sub tema 1 "Lingkungan Tempat Tinggalku" Pembelajaran 3. Penilaian terhadap RPP dilaksanakan melalui lembar pengamatan penilaian RPP dengan aspek penilaian yang terdiri dari : a) identitas mata pelajaran b)perumusan indikator pembelajaran c) perumusan tujuan pembelajaran d) pemilihan materi pembelajaran e) pemilihan sumber pembelajaran f) pemilihan media pembelajaran g) metode dan model pembelajaran $\mathrm{h}$ ) kejelasan proses pembelajaran i) kelengkapan instrument. Berdasarkan hasil penilain perencanaan pembelajaran (RPP) yang dilakukan observer, skor yang diperoleh pada Siklus I pertemuan I yaitu $75 \%$ dengan kualifikasi cukup (C).

Pelaksanaan pembelajaran tematik terpadu menggunakan model Cooperative Integrated Reading and Composition (CIRC) di kelas IV SDN 06 Piai Tangah Kota Padang siklus I pertemuan I dilaksanakan pada tema 8 daerah tempat tinggalku, sub tema $1 \quad$ Lingkungan Tempat Tinggalku Pembelajaran 3 dengan mata pelajaran yang terkait yaitu Bahasa Indonesia, PPkn dan IPS. Hasil penilaian proses pembelajaran menggunakan model CIRC yang dilakukan observer terhadap lembar pengamatan aspek guru skor yang diperoleh yaitu $78,57 \%$ dengan kualifikasi cukup (C). Kemudian pada penilain lembar pengamatan aspek peserta didik memperoleh skor yaitu 78,57\% dengan kualifikasi cukup (C).

Pada siklus I pertemuan II pada tema 8 Daerah tempat tinggalku, subtema 1 Lingkungan tempat tempat tinggalku di pembelajaran 4. Hasil penilain perencanaan pembelajaran (RPP) yang dilakukan observer memperoleh skor $83,33 \%$ dengan kualifikasi baik (B). Hasil penilaian proses pembelajaran menggunakan model CIRC dilakukan observer melalui lembar pengamatan aspek guru dengan skor yang diperoleh $89,28 \%$ dengan kualifikasi baik (B). Kemudian penilaia melalui lembar pengamatan aspek siswa memperoleh skor 89,28\% dengan kualifikasi baik (B).

Berdasarkan data hasil rencana pelaksanaan pembelajaran, maka 
hasil

$$
\text { pengamatan }
$$

rencana pelaksanaan pembelajaran pada silus I pertemuan 1 adalah $75 \%$ dengan kriteria baik. Kemudian meningkat pada siklus I pertemuan 2 menjadi $83,33 \%$ dengan kriteria sangat baik. Sehingga rata-rata rencana pelaksanaan pembelajaran pada siklus I adalah 79,16\% dengan kualifikasi baik. Untuk penilaian lembar pengmatan aspek guru siklus I pertemuan I memperoleh skor

$78,57 \%$ dengan kriteria baik dan aspek peserta didik $\quad 78,57 \%$ dengan kriteria baik, kemudian meningkat di siklus I pertemuan II pada aspek guru memperoleh skor $89,28 \%$ dengan kriteria baik dan aspek peserta didik dengan skor $89,28 \%$ dengan keriteria baik. Sehingga rata-rata hasil penilaian proses pembelajaran tematik terpadu menggunakan model CIRC dari aspek guru dan aspek peserta didik yaitu dengan skor 83.92\% dengan kualifikasi baik (B).

\section{Siklus II}

\begin{tabular}{lr}
\multicolumn{1}{c}{ Pembelajaran } & dilaksanakan \\
pada tema 8 Daerah & tempat \\
tinggalku subtema & 2 Keunikkan \\
Daerah Tempat Tinggalku & 3.
\end{tabular}

Berdasarkan hasil pengamatan rencana pelaksanaan pembelajaran tematik terpadu menggunakan model CIRC pada sikus II sudah meningkat dari siklus sebelumnya, yaitu berada pada kriteria sangat baik. Semua kekurangankekurangan yang terdapat pada rencana pelaksanaan pembelajaran pada siklus I telah diperbaiki pada pelaksanaan siklus II. Pada siklus II ini rencana pelaksanaan pembelajaran menggunakan model CIRC sudah terlaksana dengan bai.

Hasil pengamatan penilaian RPP pada siklus II meningkat dari siklus I dengan jumlah skor yang peneliti peroleh 35 dari skor maksimal 36 persentase skor yang didapat yaitu $97,22 \%$ dengan kategori sangat baik (SB). Berdasarkan perencanaan yang disusun, pelaksanaan proses pembelajaran dilaksanakan sudah sesuai dengan apa yang telah direncanakan dan mengikuti langkah-langkah model CIRC. Pada siklus II menunjukkan bahwa pelaksanaan pembelajaran tematik terpadu menggunakan model CIRC terlihat sudah meningkat dari siklus sebelumnya.

Berdasarkan data hasil pengamatan aspek guru pada siklus Il diperoleh persentase penilaian $92,85 \%$ dengan kualifikasi (SB). Kemudian data hasil pengamatan dari aspek peserta didik diperoleh persentase penilaian 92,85\% dengan kualifikasi (SB).

Setelah melihat pemaparan diatas, dapat disimpulkan bahwa pelaksanaan pembelajaran dengan model CIRC di kelas IV SD Negeri 06 Piai Tangah Kota Padang pada siklus II ini telah terlaksana dengan maksimal dan memperoleh predikat keberhasilan sangat baik (SB). Hal ini sesuai dengan keunggulan model CIRC yang disampaikan Shoimin (2014) kelebihan model CIRC sangat tepat untuk 1) meningkatkan keterampilan peserta didik dalam menyelesaikan soal pemecahan masalah 2) Dominasi guru dalam 
pembelajaran berkurang 3) Peserta didik termotivasi pada hasil secara teliti karena bekerja dalam kelompok 4) para peserta didik dapat memahami makna soal dan saling mengecek pekerjaannya 5) membantu peserta didik yang lemah 6) meningkatkan hasil belajar khususnya dalam menyelesaikan soal yang berbentuk pemecahan masalah

\section{E. Kesimpulan}

Rencana

pelaksanaan

pembelajaran dirancang oleh peneliti yang berperan sebagai guru di kelas IV SDN 06 Piai Tangah Kota Padang. Hasil penelitian menunjukkan bahwa pengamatan Rencana Pelaksanaan Pembelajaran (RPP) siklus I memperoleh rata-rata persentase sebesar 79,16\% karena Pemilihan sumber belajar sudah sesuai dengan model CIRC, dalam RPP sudah terdapat kesesuaian dengan sistematika/ keruntutan materi, dan sudah sesuai dengan model CIRC. Peningkatanpun terjadi pada siklus II menjadi $97,22 \%$ dengan kualifikasi sangat baik (SB) karena pemilihan materi sudah sesuai dengan karakteristik peserta didik, pemilihan sumber belajar sudah sesuai dengan model CIRC, dan pemilihan sumber belajar sudah sesuai dengan karakteristik peserta didik.

Dalam proses pembelajaran berdasarkan pengamatan yang dilakukan menggunakan lembar pengamatan aspek guru dan aspek peserta didik menunjukkan bahwa pelaksanaan proses pembelajaran belum maksimal. Hal ini terlihat dari lembar pengamatan aspek guru pada siklus I pertemuan I memperoleh persentase $78,57 \%$ dengan kualifikasi cukup (C), dan aspek peserta didik memperoleh persentase 78,57\% dengan kualifikasi cukup (C). Meningkat pada siklus I pertemuan II yaitu lembar pengamatan aspek guru memperoleh persentase $89,28 \%$ dengan kualifikasi baik (B) dan aspek peserta didik mendapat presentase $89,28 \%$ dengan

kualifikasi baik $(B)$, sehingga rata-rata persentase siklus 1 yaitu 83,92\% dengan kualifikasi baik (B). Peningkatanpun terjadi pada siklus II yaitu lembar pengamatan pada aspek guru memperoleh presentase $92,85 \%$ dengan kualifikasi sangat baik (SB) dan lembar pengamatan aspek peserta didik memperoleh presentase $92,85 \%$ dengan kualifikasi sangat baik (SB).

Berdasarkan hal ini terlihat proses pembelajaran tematik terpadu menggunakan model CIRC disimpulkan mengalami peningkatan dimulai dari siklus I sampai siklus II.

Berdasarkan hasil penelitian dan pembahasan serta simpulan yang diperoleh, dapat dikemukakan saran sebagai berikut:

1. Perencanaan, guru diharapkan dapat merancang pelaksanaan proses pembelajaran tematik terpadu dengan model CIRC, karena pemilihan model CIRC merupakan salah satu alternatif untuk meningkatkan proses pembelajaran tematik terpadu. 
2. Pelaksanaan, diharapkan guru dapat melaksanakan pembelajaran tematik terpadu dengan model, CIRC selain itu guru diharapkan mampu membimbing peserta didik melaksanakan kegiatan pembelajaran yangang berlangsung secara menyeluruh dan terarah sesuai dengan RPP yang dirancang.

\section{DAFTAR PUSTAKA}

Aris Shoimin. (2014). Model pembelajaran inofative dalam kurikulum 2013. Ar-Ruzz Media.

Muhammad Faturrhoman. (2015). Model-model pembelajaran inovatif. Ar-Ruzz Media.

Muhammad siddiq \& Reinita. (2019). Peningkatan Hasil Belajar siswa menggunakan model Cooperative tipe Course Review Horay pada pembelajaran tematik terpadu di sekolah dasar. Bahana Manajemen Pendidikan, 8(2), 4754.

Reinita, R. (2019). Pengaruh Model Cooperative Two Stay Two Stray terhadap Hasil Belajar PKn SD Siswa Sekolah. 382(Icet), 433437.

Windhasari, R. (2015). Upaya meningkatkan proses pembelajaran dan Hasil belajar IPA melalui pendekatan keterampilan proses. Jurnal Pendidikan Ke-SD-An, 1(2), 123127. 